\title{
Photobiomodulation Therapy in Recovery of Peripheral Facial Nerve Damage
}

\author{
Ji Eun Choi ${ }^{1,2}$
}

'Department of Otorhinolaryngology-Head and
Neck Surgery, Dankook University Hospital,
Cheonan, Korea
${ }^{2}$ Department of Medical Science, College of
Medicine, Dankook Univeristy, Cheonan, Korea

Received September 2, 2020

Accepted September 21, 2020

\section{Correspondence}

Ji Eun Choi

Department of Otorhinolaryngology-Head and Neck Surgery, College of Medicine, Dankook University, Dandae-ro, Dongnam-gu, Cheonan 31116, Korea

Tel.: +82-41-550-3284

Fax: +82-41-556-1090

E-mail: garimungdamail.com

(c) Korean Society for Laser Medicine and Surgery

(c) This is an open access article distributed under the terms of the Creative Commons Attribution NonCommercial License (http://creativecommons.org/ licenses/by-nc/4.0) which permits unrestricted noncommercial use, distribution, and reproduction in any medium, provided the original work is properly cited.
Photobiomodulation (PBM) therapy has been investigated to enhance and accelerate the recovery of injured peripheral nerves. Based on the wide range of benefits of PBM therapy and its clinical relevance, this study reviewed the efficacy of PBM in injured facial nerves. The search was performed in the PubMed database to find relevant articles published over the last 10 years. Four animal studies, two randomized controlled studies, one case series, and five case reports were reviewed. Despite the various parameters, functional analysis showed that PBM therapy using near-infrared irradiation has beneficial effects on the recovery of the acute phase of the damaged facial nerve, especially when related to faster functional improvement. There were no reported adverse effects of PBM therapy.

\section{Key words}

Facial nerve; Low-level laser therapy; Photobiomodulation; Bell's palsy 


\section{INTRODUCTION}

Facial nerve paralysis (FNP) is the most common cranial nerve disorder that causes a variety of functional and esthetic problems, as well as social and psychological issues. This condition can cause significant changes, such as impaired facial expression, changed taste, hyperacusis, and decreased salivation and tear secretion, and subsequently lead to interruption of face-to-face communications, decreased self-esteem, anxiety, depression, and social isolation. ${ }^{1}$ Idiopathic acute peripheral FNP, also known as Bell's palsy, constitutes $60-75 \%$ of cases with an annual incidence of 23 to 25 cases per 100,000. ${ }^{2-4}$ The etiology remains unclear, various causes have been proposed including viral, inflammatory, autoimmune and vascular. ${ }^{3}$

The treatment of FNP, particularly of Bell's palsy, is controversial due to the lack of large, prospective, randomized, and controlled trials. ${ }^{5}$ Corticosteroids is thought to limit nerve damage by reducing swelling and inflammation of the facial nerve. A previous Cochrane analysis reported that early treatment with corticosteroids can hasten recovery and adding antiviral drugs to corticosteroids may be some beneficial. ${ }^{6,7}$ Physical therapies including tailored facial exercises, biofeedback, acupuncture, massage, thermotherapy, and electrical stimulation also have been used to improve facial function. However, there is no high-quality evidence to support significant benefit. ${ }^{8}$

Low-level laser therapy (LLLT), now commonly referred to as photobiomodulation (PBM) therapy, has been introduced as a non-invasive modality to enhance the recovery of peripheral nerve damage. ${ }^{9.10}$ This light-based technique involves exposure of neural tissue to a low fluence of light in the ranging from $<1$ to $>20 \mathrm{~J} / \mathrm{cm}^{2}$ and wavelengths ranging from infrared to near infrared (NIR) (600 to 1100 $\mathrm{nm})$. The beneficial effects of PBM are thought to occur primarily by inducing a photochemical reaction in the cell, instead of generating a thermal effect. ${ }^{11}$ The wavelength of infrared irradiation is easily absorbed by tissues and the loss of intensity is minimal, affecting metabolic modifications, DNA activity, adenosine triphosphate (ATP) formation, and the mitochondrial chain.

PBM works on the principle that, when light hits certain molecules called chromophores, the photon energy causes electrons to be excited and jump from low-energy orbits to higher-energy orbits. This sorted energy can be used by the system to perform various cellular task, such as photosynthesis and photomorphogenesis. ${ }^{11} \mathrm{Cy}$ tochrome c oxidase (CCO) in the mitochondrial respiratory chain probably acts as an important chromophore in action mechanism of PBM therapy. ${ }^{12,13}$ Mitochondrial $\mathrm{CCO}$ absorbs light energy in the red and the NIR spectral regions and PBM increases its catalytic activity. Consequently, the PBM cause photodissociation of nitric oxide (NO) from CCO, leading to an increase in electron transport, mitochondrial membrane potential and ATP production. All these results in enhancement of neuronal respiration and metabolic capacity. On the other hand, the PBM activates light-sensitive ion channels that can be activated allowing calcium to enter the cell. After then, numerous signaling pathways are activated via calcium ions $\left(\mathrm{Ca}^{2+}\right)$, reactive oxygen species (ROS), cyclic AMP, and $\mathrm{NO}$ and, leading to activation of transcription factors. ${ }^{14,15}$ These transcription factors can lead to increased expression of genes related to protein synthesis, cell migration and proliferation, anti-inflammatory signaling, anti-apoptotic proteins, antioxidant enzymes. Thus, photochemical and photobiological effects of PBM at the cellular level can lead to improvement of trophic conditions related to the process of peripheral nerve regeneration and promote the secretion of neural factors.

Since 1980, the scientific interest in the therapeutic approach of rehabilitation for FNP was initiated due to the good results with the use of PBM therapy in the recovery of injured peripheral nerves. However, there are still difficulties in selecting the most suitable parameters for application to facial nerves due to the lack of standardization. The treatment parameters of PBM therapy such as wavelength, fluence, power density, number of repetitions, duration of treatment, and the mode of light delivery (continuous or pulsed) have repercussions on the biological effects. ${ }^{16}$ Due to the various treatment parameters of PBM therapy and its benefits, the aim of this research was to carry out a review of the papers published in the last 10 years verifying the relation of PBM therapy with the recovery of injured peripheral facial nerves.

\section{MATERIALS AND METHODS}

A search was performed in the PubMed database over the last 10 years and restricted to the English language. The selected keywords were ("Low-level laser" OR "photobiomodulation" OR "phototherapy") AND ("Bell's palsy" OR "facial palsy" OR "facial paralysis" OR "facial nerve injury"). The author also provided hand search of the references of the selected studies to identify other possible relevant studies. The articles included should necessarily be presented with full access to the text. We verified those articles that presented titles and summaries that approached the subject of this research, as well as method- 
ology, results, and relevance for tis practical application.

\section{RESULT}

Finally, 12 relevant articles were obtained from the PubMed database. Four studies used animals as a study object (Table 1). ${ }^{17-20}$ All animal studies used male Wistar rats aged 60-80 days. One study evaluated the effect of PBM on compression of main trunk $k^{20}$ and 3 articles evaluated its effect on neurotmeses of buccal branch. ${ }^{17-19}$ The wavelength of $830 \mathrm{~nm}$ of PBM therapy presented better morphological (especially, fiber areal and functional nerve repair in damaged terminal branches of the facial nerve that were repaired accelerated morphological and functional nerve repair by suture or fibrin sealant. ${ }^{17-19}$ Recent PBM study on damaged main trunk of FN also showed a better healing process than the control group, but the outcome was not statistically significant. ${ }^{20}$ The main difference between recent study and previous studies was the energy density $\left(3.2 \mathrm{~J} / \mathrm{cm}^{2}\right.$ in recent study ${ }^{20}$ vs. 6-6.2 J/ $\mathrm{cm}^{2}$ in previous studies. ${ }^{17-19}$

Of 8 human studies, 2 studies were designed as randomized controlled study $(\mathrm{RCT})^{21,22}$ and 6 studies were descriptive studies (Table 2). ${ }^{23-28}$ One study had two parallel RCT design, the LLLT group and control group. ${ }^{21}$ The other study had three parallel RCT design including highlevel laser therapy, LLLT group, and control group. ${ }^{22}$ Two RCT studies applied both exercise and massage therapy in their control groups, and these exercise and massage therapy were accompanied as parts of treatment in the intervention groups. Two RCT studies used 830 $\mathrm{nm}$ wavelength with the energy density of $10 \mathrm{~J} / \mathrm{cm}^{2}$ for a total of 18 treatment sessions over a period of 6 weeks in LLLT groups. Researchers of these RCT studies reported significant improvement on the physical and social facial disability index (PFDI and SFDI) following LLLT at the ending of their treatment sessions (Table 3). Of 6 descriptive studies, one study was clinical intervention study on effect of LLLT in diabetics with bell's palsy ${ }^{23}$ and 5 articles were case report. ${ }^{24-28}$ These descriptive studies applied NIR range of wavelength with various number of treatment session and period of treatment (Table 2). All researchers in the descriptive studies reported improvement of Bell's palsy on House-Brackman (H-B) grade following LLLT at the ending of their treatment sessions. The effect of LLLT on the treatment of Bell's palsy has also been reported in

Table 1. Data of selected animal studies

\begin{tabular}{|c|c|c|c|c|}
\hline Author (year) & Surgical procedures & Laser protocol & Evaluation time & Main results \\
\hline Buchaim et al. $(2016)^{17}$ & $\begin{array}{l}\text { Neurotmeses of BB of FN, } \\
\text { followed by end-to-end } \\
\text { suture (right FN) or } \\
\text { coaptation with } \\
\text { heterologous fibrin } \\
\text { sealant (left FN) }\end{array}$ & $\begin{array}{l}\text { GaAlAs laser, } 830 \mathrm{~nm}, 258.6 \\
\mathrm{~mW} / \mathrm{cm}^{2}, 6 \mathrm{~J} / \mathrm{cm}^{2}, 24 \mathrm{~s} / \text { point } \\
\text { for } 3 \text { points on the surgical } \\
\text { site, performed } 1 \text { st day after } \\
\text { surgery and } 3 \text { times/week } \\
\text { for } 5 \text { weeks in the postop- } \\
\text { erative period }\end{array}$ & $\begin{array}{l}\text { Morphological evaluation } \\
\text { at } 5 \text { and } 10 \text { weeks after } \\
\text { the surgery }\end{array}$ & $\begin{array}{l}\text { LLLT showed satisfactory } \\
\text { results on facial nerve } \\
\text { regeneration. }\end{array}$ \\
\hline Buchaim et al. $(2017)^{19}$ & $\begin{array}{l}\text { Neurotmeses of BB of FN, } \\
\text { followed by end-to-end } \\
\text { suture (right FN) or } \\
\text { coaptation with } \\
\text { heterologous fibrin } \\
\text { sealant (left FN) }\end{array}$ & $\begin{array}{l}\text { GaAlAs laser, } 830 \mathrm{~nm}, 258.6 \\
\mathrm{~mW} / \mathrm{cm}^{2}, 6.2 \mathrm{~J} / \mathrm{cm}^{2}, 24 \mathrm{~s} / \\
\text { point for } 3 \text { points on the } \\
\text { surgical site, performed } \\
1 \text { st day after surgery and } 3 \\
\text { times/week for } 5 \text { weeks in } \\
\text { the postoperative period }\end{array}$ & $\begin{array}{l}\text { Functional analysis and } \\
\text { morphological evaluation } \\
\text { at } 5 \text { and } 10 \text { weeks after the } \\
\text { surgery }\end{array}$ & $\begin{array}{l}\text { LLLT stimulated axonal } \\
\text { regeneration accelerated the } \\
\text { process of functional recovery } \\
\text { of whisker }\end{array}$ \\
\hline Rosso et al. $(2017)^{18}$ & $\begin{array}{l}\text { Neurotmeses of BB of FN, } \\
\text { followed by end-to-side } \\
\text { sutured to the ZB of the FN } \\
\text { (right FN) or coaptation with } \\
\text { heterologous fibrin sealant } \\
\text { (left FN) }\end{array}$ & $\begin{array}{l}\text { GaAlAs laser, } 830 \mathrm{~nm}, 260 \\
\mathrm{~mW} / \mathrm{cm}^{2}, 6.2 \mathrm{~J} / \mathrm{cm}^{2}, 24 \mathrm{~s} / \\
\text { point for } 3 \text { points on the } \\
\text { surgical site, performed im- } \\
\text { mediately after surgery and } \\
3 \text { times/week for } 5 \text { weeks in } \\
\text { the postoperative period }\end{array}$ & $\begin{array}{l}\text { Functional analysis and } \\
\text { morphological evaluation } \\
\text { at } 10 \text { weeks after the } \\
\text { surgery }\end{array}$ & $\begin{array}{l}\text { LLLT provided better } \\
\text { morphological and functional } \\
\text { repair in the two techniques } \\
\text { used. }\end{array}$ \\
\hline Yuca et al. $(2020)^{20}$ & $\begin{array}{l}\text { Crush the injury to the main } \\
\text { trunk of FN for } 30 \text { s using } \\
\text { surgical clamp to create } \\
\text { neuropathic damage (left FN) }\end{array}$ & $\begin{array}{l}\text { Superluminescent diode, } 850 \\
\mathrm{~nm}, 100 \mathrm{~mW} / \mathrm{cm}^{2}, 3.2 \mathrm{~J} / \mathrm{cm}^{2}, \\
32 \mathrm{~s} \text { on the surgical site for } \\
21 \text { consecutive days }\end{array}$ & $\begin{array}{l}\text { Morphological evaluation } \\
\text { at } 3 \text { weeks after the } \\
\text { surgery }\end{array}$ & $\begin{array}{l}\text { LLLT revealed a better healing } \\
\text { process than the control } \\
\text { group, but the outcome was } \\
\text { not statistically significant }\end{array}$ \\
\hline
\end{tabular}

BB, buccal branch; FN, facial nerve; GaAlAs, gallium-aluminum-arsenide; s, seconds; ZB, zygomatic branch; LLLT, low-level laser therapy. 


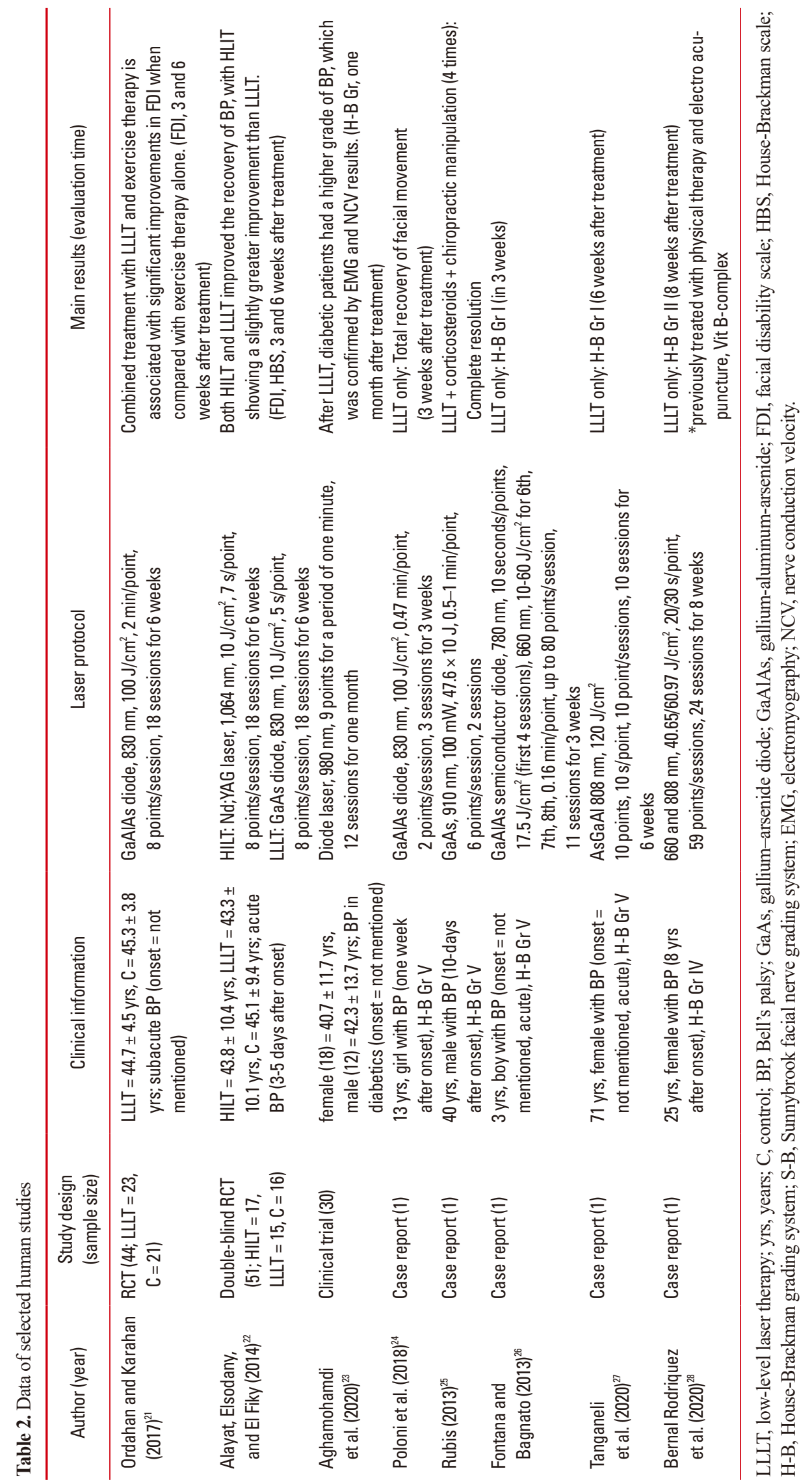


Table 3. FDI scores of studies by Ordahan and Karahan (2017) and Alayat, Elsodany, and El Fiky (2014)

\begin{tabular}{|c|c|c|c|c|c|c|c|}
\hline \multirow{2}{*}{ Study } & \multirow{2}{*}{ Groups } & \multicolumn{3}{|c|}{ PFDI } & \multicolumn{3}{|c|}{ SFDI } \\
\hline & & Before & 3 weeks & 6 weeks & Before & 3 weeks & 6 weeks \\
\hline \multirow{3}{*}{$\begin{array}{l}\text { Ordahan and Karahan } \\
(2017)^{21}\end{array}$} & LLLTG & $27.05 \pm 14.13$ & $37.42 \pm 8.13^{*}$ & $39.21 \pm 9.08^{*}$ & $22.80 \pm 18.76$ & $35.41 \pm 10.12^{*}$ & $37.53 \pm 9.65^{*}$ \\
\hline & CG & $26.52 \pm 11.07$ & $25.41 \pm 13.12$ & $29.06 \pm 11.09^{*}$ & $23.40 \pm 15.23$ & $23.25 \pm 15.27$ & $28.76 \pm 12.14^{*}$ \\
\hline & $p$-values & ns & $<0.05^{* *}$ & $<0.05^{* *}$ & ns & $<0.05^{* *}$ & $<0.05^{* *}$ \\
\hline \multirow{4}{*}{$\begin{array}{l}\text { Alayat, Elsodany, and } \\
\text { El Fiky }(2014)^{22}\end{array}$} & HILTG & 20.06 & $37.41^{*}$ & $39.74^{*}$ & 21.91 & $39.21^{*}$ & $38.47^{*}$ \\
\hline & LLLTG & 27.06 & $25.53^{*}$ & $21.8^{*}$ & 28.77 & $22.33^{*}$ & $25.73^{*}$ \\
\hline & CG & 26.84 & $9.81^{*}$ & $10.84^{*}$ & 23.25 & $10.91^{*}$ & $8.5^{*}$ \\
\hline & $p$-values & ns & $<0.01^{* *}$ & $<0.01^{* *}$ & ns & $<0.01^{* *}$ & $<0.01 * *$ \\
\hline
\end{tabular}

PFDI, physical facial disability index; SFDI, social facial disability index; LLLTG; low-level laser therapy group; CG, control group; HILTG, high intensity laser therapy group; ns, not significant.

${ }^{*} p<0.001=$ significant differences in intra-group evaluation according to baseline (before treatment) using Friedman analysis and post-hoc analysis with Bonferroni correction.

${ }^{* *} p<0.05=$ significant differences among the treatment groups using Mann-Whitney U test or Kruskal Wallis test.

diabetic patients, ${ }^{23}$ children, ${ }^{26,29}$ and chronic Bell's palsy. ${ }^{28}$ When reviewed the human studies, there were no reported adverse effects during treatment and/or follow-up sessions.

\section{DISCUSSION}

This study aimed to review the papers published in the last 10 years in order to verify the effects of PBM therapy on the recovery of peripheral facial nerve damage. Totally, 4 relevant animal studies and 8 human studies were reviewed. The functional analysis in both animal and human studies evidenced the recovery of FN associated with LLLT with wavelengths ranging from NIR 1600 to $1100 \mathrm{~nm}$ ). Previous animal studies have demonstrated that PBM in the nerve injury was related to reduced inflammatory cytokine and elevated expression of neural growth factor (NGF) and brain-derived neurotrophic factor (BDNF) ${ }^{30-33}$ However, there was no studies on the mechanism of PBM therapy on the regeneration of damaged facial nerve. All human studies were designed to evaluate effects of LLLT on Bell's palsy recovery. Except one case report, all studies started LLLT in acute or subacute stage of nerve damages. Therefore, it was difficult to conclude the effect of LLLT in chronic stage of nerve damages.

In summary, relevant evidences cautiously suggested that LLLT with wavelengths ranging from NIR can effectively improve the recovery of acute facial nerve damage. However, the relevant human studies were mostly case report or case series that rank lowly in level of evidences. Since there were only two RCTs included in this review, it is difficult to generalize clinical results. Thus, further
RCTs with enlarged sample sizes and other objective outcome measures are needed. In addition, animal studies on the effect of PBM on the regeneration of damaged facial nerves are needed to support the clinical results.

\section{FUNDING}

This work was supported by the National Research Foundation of Korea (NRF) grant funded by the Ministry of Science and ICT (MSIT) (2019R1H1A1035610).

\section{REFERENCES}

1. Chang YS, Choi JE, Kim SW, Baek SY, Cho YS. Prevalence and associated factors of facial palsy and lifestyle characteristics: data from the Korean National Health and Nutrition Examination Survey 2010-2012. BMJ Open 2016;6:e012628.

2. Holland J. Bell's palsy. BMJ Clin Evid 2008;2008:1204.

3. Katusic SK, Beard CM, Wiederholt WC, Bergstralh EJ, Kurland LT. Incidence, clinical features, and prognosis in Bell's palsy, Rochester, Minnesota, 1968-1982. Ann Neurol 1986;20:622-7.

4. Martyn CN, Hughes RA. Epidemiology of peripheral neuropathy. J Neurol Neurosurg Psychiatry 1997;62:310-8.

5. Türk-Börü $U$, Koçer $A$, Bilge $C$. The efficacy of steroids in idiopathic facial nerve paralysis: an open, randomized, prospective controlled study. Kulak Burun Bogaz Ihtis Derg 2005;14:62-6.

6. Madhok VB, Gagyor I, Daly F, Somasundara D, Sullivan M, Gammie F, et al. Corticosteroids for Bell's palsy lidiopathic facial paralysis). Cochrane Database Syst Rev 2016;7:CD001942.

7. Gagyor I, Madhok VB, Daly F, Sullivan F. Antiviral treatment for Bell's palsy (idiopathic facial paralysis). Cochrane Database Syst Rev 2019;9:CD001869.

8. Teixeira LJ, Valbuza JS, Prado GF. Physical therapy for Bell's 
palsy (idiopathic facial paralysis). Cochrane Database Syst Rev 2011;(12):CD006283.

9. Rosso MPO, Buchaim DV, Kawano N, Furlanette G, Pomini KT, Buchaim RL. Photobiomodulation therapy (PBMT) in peripheral nerve regeneration: a systematic review. Bioengineering (Basel) 2018;5:44.

10. Andreo L, Soldera CB, Ribeiro BG, de Matos PRV, Bussadori SK, Fernandes KPS, et al. Effects of photobiomodulation on experimental models of peripheral nerve injury. Lasers Med Sci 2017;32:2155-65.

11. Hashmi JT, Huang YY, Osmani BZ, Sharma SK, Naeser MA, Hamblin MR. Role of low-level laser therapy in neurorehabilitation. PM R 2010;2(12 Suppl 2):S292-305.

12. Karu TI, Kolyakov SF. Exact action spectra for cellular responses relevant to phototherapy. Photomed Laser Surg 2005;23:355-61.

13. Ball KA, Castello PR, Poyton RO. Low intensity light stimulates nitrite-dependent nitric oxide synthesis but not oxygen consumption by cytochrome c oxidase: Implications for phototherapy. J Photochem Photobiol B 2011;102:182-91.

14. Dompe C, Moncrieff L, Matys J, Grzech-Leśniak K, Kocherova I, Bryja A, et al. Photobiomodulation-underlying mechanism and clinical applications. J Clin Med 2020;9:1724.

15. Morries LD, Cassano P. Henderson TA. Treatments for traumatic brain injury with emphasis on transcranial near-infrared laser phototherapy. Neuropsychiatr Dis Treat 2015;11:2159-75.

16. Ginani F, Soares DM, Barreto MP, Barboza CA. Effect of lowlevel laser therapy on mesenchymal stem cell proliferation: a systematic review. Lasers Med Sci 2015;30:2189-94.

17. Buchaim DV, Rodrigues Ade C, Buchaim RL, Barraviera B, Junior RS, Junior GM, et al. The new heterologous fibrin sealant in combination with low-level laser therapy (LLLT) in the repair of the buccal branch of the facial nerve. Lasers Med Sci 2016;31:965-72.

18. Rosso MPO, Rosa Júnior GM, Buchaim DV, German IJS, Pomini KT, de Souza RG, et al. Stimulation of morphofunctional repair of the facial nerve with photobiomodulation, using the end-to-side technique or a new heterologous fibrin sealant. J Photochem Photobiol B 2017;175:20-8.

19. Buchaim DV, Andreo JC, Ferreira Junior RS, Barraviera B, Rodrigues AC, Macedo MC, et al. Efficacy of laser photobiomodulation on morphological and functional repair of the facial nerve. Photomed Laser Surg 2017;35:442-9.

20. Yuca Y, Yucesoy T, Tok OE, Alkan A. The efficiency of ozone therapy and low-level laser therapy in rat facial nerve injury. J Craniomaxillofac Surg 2020;48:308-14.

21. Ordahan B, Karahan AY. Role of low-level laser therapy added to facial expression exercises in patients with idiopathic facial (Bell's) palsy. Lasers Med Sci 2017;32:931-6.

22. Alayat MS, Elsodany AM, El Fiky AA. Efficacy of high and low level laser therapy in the treatment of Bell's palsy: a randomized double blind placebo-controlled trial. Lasers Med Sci 2014;29:335-42.

23. Aghamohamdi D, Fakhari S, Farhoudi M, Farzin H. The efficacy of low-level laser therapy in the treatment of Bell's palsy in diabetic patients. J Lasers Med Sci 2020;11:310-5.

24. Poloni MM, Marques NP, Ribeiro Junior NV, Sperandio FF, Hanemann JAC, de Carli ML. Bell's palsy treated with photobiomodulation in an adolescent: rare case report and review of the published literature. Int J Paediatr Dent 2018;28:658-62.

25. Rubis LM. Chiropractic management of Bell palsy with low level laser and manipulation: a case report. J Chiropr Med 2013;12:288-91.

26. Fontana CR, Bagnato VS. Low-level laser therapy in pediatric Bell's palsy: case report in a three-year-old child. J Altern Complement Med 2013;19:376-82.

27. Tanganeli JPC, de Oliveira SSI, da Silva T, Fernandes KPS, Motta LJ, Bussadori SK. Complete and fast recovery from idiopathic facial paralysis using laser-photobiomodulation. Case Rep Dent 2020;2020:9867693.

28. Bernal Rodriguez CG, Berlingieri Polho I, Azevedo LH, de Paula Eduardo C. Photobiomodulation therapy to treat facial paralysis of 8 years: case report. Photobiomodul Photomed Laser Surg 2020;38:477-80.

29. Ton G, Lee LW, Chen YH, Tu CH, Lee YC. Effects of laser acupuncture in a patient with a 12-year history of facial paralysis: a case report. Complement Ther Med 2019;43:306-10.

30. Wang CZ, Chen YJ, Wang YH, Yeh ML, Huang MH, Ho ML, et al. Low-level laser irradiation improves functional recovery and nerve regeneration in sciatic nerve crush rat injury model. PLoS One 2014;9:e103348.

31. Chen YJ, Wang YH, Wang CZ, Ho ML, Kuo PL, Huang MH, et al. Effect of low level laser therapy on chronic compression of the dorsal root ganglion. PLoS One 2014;9:e89894.

32. de Oliveira Martins D, Martinez dos Santos F, Evany de Oliveira M, de Britto LR, Benedito Dias Lemos J, Chacur M. Laser therapy and pain-related behavior after injury of the inferior alveolar nerve: possible involvement of neurotrophins. J Neurotrauma 2013;30:480-6.

33. Gomes LE, Dalmarco EM, Andre ES. The brain-derived neurotrophic factor, nerve growth factor, neurotrophin-3, and induced nitric oxide synthase expressions after low-level laser therapy in an axonotmesis experimental model. Photomed Laser Surg 2012;30:642-7.

How to cite this article: Choi JE. Photobiomodulation therapy in recovery of peripheral facial nerve damage. Med Lasers 2020;9:89-94. https://doi.org/10.25289/ML.2020.9.2.89 